\title{
Pengembangan Program Pembelajaran Pendidikan Agama Islam dalam Meningkatkan Budaya Keagamaan di SDN Bletok Bungatan Situbondo
}

\author{
Muhammad Azizi \\ Institut Pesantren KH. Abdul Chalim Mojokerto \\ jejefaqod@gmail.com
}

\begin{abstract}
Abstrak
Pengembangan budaya keagamaan di sekolah merupakan suatu kewajiban yang harus dilaksanakan oleh sekolah dengan mendesain program pendidikan agama islam yang mengarah pada pengembangan budaya keagamaan. Fokus penelitian ini adalah Bagaimana perencanaan pengembangan program pembelajaran Pendidikan Agama Islam dalam meningkatkan budaya keagamaan di SDN Bletok Bungatan Situbondo? Bagaimana pelaksanaan pengembangan program pembelajaran Pendidikan Agama Islam dalam meningkatkan budaya keagamaan di SDN Bletok Bungatan Situbondo? dan Bagaimana pengawasan pengembangan program pembelajaran Pendidikan Agama Islam dalam meningkatkan budaya keagamaan di SDN Bletok Bungatan Situbondo? Penelitian ini menggunakan pendekatan deskriptif analisis, jenis studi kasus. Teknik pengumpulan data menggunakan wawancara, observasi, dan dokumentasi. Analisis data menggunakan model interaktif dan keabsahan data menggunakan triangulasi sumber. Hasil dari penelitian ini menunjukkan: 1) Perencanaan pengembangan program pembelajaran pendidikan agama islam dalam meningkatkan budaya keagamaan di SDN Bletok Bungatan Situbondo, yaitu: penyusunan buku pintar, Penugasan anggota membuat rancangan kegiatan, nilai-nilai karakter prioritas utama, rencana strategis pendekatan botton up, perencanaan pengembangan budaya keagamaan oleh tim agama. 2) Pelaksanaan pengembangan program pembelajaran pendidikan agama islam dalam meningkatkan budaya keagamaan di SDN Bletok Bungatan Situbondo, yaitu: Roling tanggung jawab job deskription pengembangan budaya, Quality Insurence (Jaminan Mutu) pembiasaan keagamaan, Model uswah guru, pelaksanaan Budaya keagamaan. 3) Pengawasan pengembangan program pembelajaran pendidikan agama islam dalam meningkatkan budaya keagamaan di SDN Bletok Bungatan Situbondo, yaitu: pengawasan internal kinerja anggota dan eksternal melalui pengguna layanan siswa dan orang tua, evaluasi supervisor sekolah terhadap kinerja anggota, anak berkepribadian sesuai dengan nilai-nilai agama,
\end{abstract}


monitoring oleh komponen sekolah dan tim agama, monitoring siswa, monitoring tingkah laku dan pembiasaan siswa, penetapan capaian dari Quality Insurence.

\section{Kata Kunci: Pembelajaran; Pendidikan Agama Islam; Budaya Keagamaan}

\section{PENDAHULUAN}

Suatu kenyataan yang dihadapi dunia pendidikan khususnya Pendidikan Agama Islam di lembaga pendidikan formal saat ini, adalah rendahnya kualitas manajerial pembelajaran baik pada tataran perencanaan, pelaksanaan maupun cara pengendaliannya, akibatnya proses pembelajaran pendidikan Agama Islam kurang berhasil dalam pembentukan perilaku positif siswa. Lemahnya aspek metodologi yang dikuasai oleh guru juga merupakan penyebab rendahnya kualitas pembelajaran. Metode yang banyak dipakai adalah model konvensional yang kurang menarik. Ketidakberdayaan pendidikan agama dalam menginternalisasikan nilai-nilai agama juga merupakan salah satu faktor penyebab munculnya out put yang tidak mampu mengemban misi pendidikan nasional yaitu menjadi manusia yang beriman dan bertaqwa kepada Allah SWT. Oleh karenanya, rekonstruksi terhadap manajemen program-program pembelajaran agama mutlak dilakukan demi tercapainya tujuan yang diharapkan.

Pendidikan adalah usaha sadar dan terencana untuk mewujudkan suasana belajar dan proses pembelajaran agar peserta didik secara aktif mengembangkan potensi dirinya untuk memiliki kekuatan spiritual keagamaan, pengendalian diri, kepribadian, kecerdasan, akhlak mulia, serta keterampilan yang diperlukan dirinya, masyarakat, bangsa dan negara, karena pendidikan merupakan tugas dan tanggung jawab bersama antara keluarga, masyarakat, dan pemerintah. Di dalam Undang-Undang Dasar 1945 pasal 31 tentang pendidikan menyebutkan antara lain pemerintah memajukan ilmu pengetahuan dan teknologi dengan menjunjung tinggi nilai nilai agama dan persatuan bangsa untuk kemajuan peradaban serta 
kesejahteraan umat manusia. ${ }^{1} \mathrm{Hal}$ ini menunjukkan pendidikan berorientasi ke masa depan dengan bertumpu pada potensi sumber daya manusia dan kekuatan budaya masyarakat, sehingga meningkatkan mutu manusia dan masyarakat. Peningkatan mutu pendidikan Islam memperhatikan pengembangan kecerdasan rasional dalam rangka memacu penguasaan nilai-nilai agama Islam dan ilmu pengetahuan serta teknologi di samping memperkokoh kecerdasan emosional, sosial, dan spiritual.

Pendidikan Agama Islam dikembangkan dengan menempatkan nilainilai agama dan budaya luhur bangsa sebagai spirit dalam proses pengelolaan dan pembelajaran. Hal ini ditunjukan antara lain dengan mengintegrasikan wawasan keagamaan pada kurikulum pendidikan, menciptakan suasana keberagamaan pada kurikulum pendidikan, mengutamakan keteladanan dalam perilaku dan amalan keagamaan pengelola dan pendidik, menyediakan dukungan bahan dan sarana pembelajaran seperti kitab suci, buku referensi keagamaan dan tempat ibadah. Namun demikian, pelaksanaan kurikulum pendidikan terkadang masih belum sepenuhnya menjadi alat perubahan nilai budaya masyarakat, tetapi masih lebih mengutamakan mengajarkan nilai-nilai budaya lama. Peserta didik kurang dibekali dengan realitas yang berkaitan dengan hakekat hidup dan kehidupan sehari-hari yang dialami di lingkungan tempat tinggalnya. Peserta didik lebih diarahkan untuk memperoleh ijazah setinggitinggi dan mempersiapkannya untuk menjadi pegawai dalam suatu instansi dan kurang menstimulus mereka untuk menjadi seorang peserta didik yang berbudaya, khususnya budaya keberagamaan.

Pelaksanaan proses pembelajaran pendidikan agama Islam berorientasi pada penerapan Standar Nasional Pendidikan. Dalam proses pembelajaran bukan hanya terjadi transfer ilmu pengetahuan dari guru kepada peserta didik atau dari peserta didik kepada peserta didik lainnya,

\footnotetext{
${ }^{11}$ Undang-Undang Republik Indonesia Nomor 11 Tahun 2019 Tentang Sistem Nasional Ilmu Pengetahuan Dan Teknologi.
} 
namun juga terjadi proses transfer kebudayaan yaitu terjadinya penanaman nilai-nilai, norma-norma, atau adat kebiasaan. Peserta didik adalah subjek yang melakukan akulturasi kebudayaan. Peserta didik mempelajari dan mengamalkan nilai, norma, atau kebiasaan yang ada di masyarakat. Untuk itu dilakukan kegiatan-kegiatan seperti pengembangan metode pembelajaran pendidikan agama Islam, pengembangan kultur budaya Islami dalam proses pembelajaran, dan pengembangan kegiatan-kegiatan kerokhanian Islam dan ekstrakurikuler.

Dalam pembelajaran pendidikan agama Islam, menanamkan nilai-nilai yang Islami ke dalam hati sanubari umat manusia khususnya umat islam. Dalam ajaran Islam, tidak ada satu orang muslimpun yang ingin dilihat oleh Allah SWT berbuat dosa, berbuat salah dan melakukan perbuatan-perbuatan yang buruk dan melanggar nilai-nilai dan norma-norma baik habuluminallah maupun habluminannas. ${ }^{2}$

Dalam rangka menindaklanjuti hal tersebut maka dilaksanakan kegiatan yang langsung melibatkan pelaku utama pendidikan yaitu peserta didik. Wujud dari kegiatan ini antara lain diselenggarakannya kegiatan keterampilan dan seni pendidikan agama Islam. Kegiatan ini sangat penting dalam rangka memberikan semangat dan gairah baru bagi para pendidik, peserta didik, atau yang memiliki tugas dan tanggung jawab dalam penyelenggaraan pendidikan di sekolah. Selain itu juga diharapkan kegiatan ini dapat menumbuhkan budaya keberagamaan di lingkungan sekolah.

Penelitian ini mengangkat tema Pengembangan program pembelajaran Pendidikan Agama Islam dalam Meningkatkan Budaya Keagamaan di SDN Bletok Kecamatan Bungatan Kabupaten Situbondo. Dipilihnya SDN Bletok Kecamatan Bungatan sebagai lokasi obyek penelitian karena lembaga ini dikelola secara profesional dan tetap bertumpu pada nilai kultural

\footnotetext{
${ }^{2}$ Suyadi, Pelaksanaan Pembelajaran Pendidikan Agama Islam (PAI) DI SMK NEGERI 1 Lais Kecamatan Lais Kabupaten Musi Banyuasin, Jurnal Conciencia, Vol. 14 No 1 (2014), 37. [https://doi.org/10.19109/conciencia.v14i1]
} 
keagamaan. Sisi keunggulannya dibandingkan dengan sekolah konvensional adalah: Three in one (pola pendidikan multi dimensi), Paket kurikulum mencerminkan pola pendidikan integratif antara keilmuan, keagamaan, kebangsaan dan kebahasaan.

SDN Bletok Kecamatan Bungatan bertujuan mencetak manusia Indonesia yang unggul, (berkualitas tinggi) seperti yang tercantum dalam tujuan Pendidikan Nasional, Secara garis besar, SDN Bletok diarahkan utuk mencetak kader bangsa yang memiliki komitmen (1) keislaman, (2) kebangsaan, (3) kecendikiaan. Sistem pengelolaan SDN Bletok mengacu pada standar mutu UNESCO, yaitu sekolah yang dapat menerapkan empat pilar pembelajaran sebagai gerbang pembebasan anak, yaitu (1) bagaimana anak belajar untuk belajar (how learn to learn), (2) bagaimana anak belajar untuk berbuat (haw learn to do) (3) bagaimana anak belajar untuk mengenal dan menjadi menurut dirinya sendiri (how learn to be), dan (4) bagaimana anak untuk belajar hidup berdampingan dalam kebersamaan dengan yang lain (how learn to life together). ${ }^{3}$

Untuk bisa mewujudkan tujuan kelembagaan tersebut dibentuklah tim penanggung jawab 8 standar pendidikan dan tim pengembang agama islam. Tim pengembang agama Islam terdiri atas guru berlatar sarjana agama islam. Mereka memiliki sertifikasi trainer ESQ. Pelatihan ESQ untuk pembinaan akhlak dan kecerdasan spiritual siswa serta meningkatkan motifasi belajar. Penerapan sistem nilai yang berhubungan dengan aspek agama sanagat diupayakan, diantaranya adalah :

1. Penerapan sistem nilai yang berhubungan dengan aspek agama dalam hal memulai dan mengakhiri pelajaran

2. Penerapan sistem nilai berhubungan dengan aspek agama mengenai tauhid, keyakinan, dan ibadah

\footnotetext{
${ }^{3} \mathrm{http} / / /$ www.unesco.org/delors/fourpil.htm, diakses pada 14 Oktober 2020.
} 
3. Penerapan sitem nilai yang berhubungan dengan aspek agama dalam hal kesabaran untuk menghadapi kesulitan.

4. Penerapan sistem Nilai yang behubungan dengan aspek agama dalam hal semangat dan kesungguhan belajar

5. Penerapan sistem nilai yang berhubungan dengan aspek agama dalam hal kerendahan hati/ tawaddu'.

Penerapan sistem nilai berhubungan dengan aspek agama mengenai tauhid, keyakinan, dan ibadah di SDN Bletok terbentuk dalam pembiasaanpembiasan Keagamaan dalam setiap harinya meliputi: 1) Pembelajaran A1Qur'an, 2) Sholat Dhuha yang sebelumnya diawali dengan membaca shalawat Nariyah, 3) Mudarosah surat-surat pendek secara klasikal, 4) Petugas muadzin dan iqamah adalah siswa, 5) Antara adzan dan iqamah siswa membaca hafalan yang telah diberikan oleh Tim Agama, 6) Shalat dhuhur berjamaah dilanjutkan dengan pembelajaran pembiasaan membaca al-barzanji, 7) Mengakhiri kegiatan pembelajaran disekolah dengan cara berdo'a serta melafalkan Asmaul Khusnah bersama-sama, dan 8) Siswa dibiasakan mengucapkan salam dan berjabat tangan ketika datang dan pulang sekolah. ${ }^{4}$

Budaya keagamaan di SDN Bletok sangat mewarnai dalam kehidupan sekolah mulai mengawali pembelajaran sampai mengahiri pembelajaran disekolah, SDN Bletok menpunyai Quality Insurence (Jaminan Mutu) dibidang keagamaan. Jaminan mutu tersebut memberikan potret lulusan SDN Bletok pada masyarakat secara umum. ${ }^{5}$

Peneliti kemudian ingin mendalmi tentang foneman yang ada di SDN Bletok terhadap beberapa kegiatan yang menjadi program di SDN Bletok karena cakupan kegiatan tersebut bukan hanya bertumpu pada pengembangan kognitif siswa tetapi lebih meluas terhadap beberapa kebiasan siswa di sekolah yang ditekankan pada pemahaman terhadap

\footnotetext{
${ }^{4}$ Dokumentasi SDN Blitok Tanggal 8 Juli 2020.

${ }^{5}$ Observasi awal di SDN Bletok tanggal 8 Juli 2020
} 
budaya keagamaan dan pembiasaan selalu mengimplementasikan nilai-nilai luhur ajaran agama islam.

Berdasarkan kajian pendahuluan di atas, dan karena masih sedikitnya lembaga pendidikan SD di Bungatan yang melakukan penerapan pembiasaan keagamaan seperti pada SDN Bletok Bungatan, maka penulis memandang perlu melakukan penelitian untuk mengetahui lebih mendalam berkait dengan bagaimana Pengembangan pembelajaran pendidikan agama Islam dalam meningkatkan budaya keagamaan di SDN Bletok Kecamatan Bungatan Kabupaten Situbondo, sehingga dapat diterapkan dan dilaksanakan oleh siswa dengan disiplin dan penuh tanggung jawab.

\section{METODE PENELITIAN}

Penelitian ini menggunakan pendekatan deskriptif analisis, dengan jenis studi kasus di SDN Bletok yang beralamatkan di Jl. KH Abu Bakar, Bletok, Kec. Bungatan, Kab. Situbondo Prov. Jawa Timur, sumber data yang diambil dari data primer dan sekunder, untuk informan penelitian ini, menggunakan tehnik purpossive sampling dan penggunaan snowball sampling sedangkan Teknik Pengumpulan Data, Teknik Wawancara Mendalam (indepth wawancara) Observasi, dan Metode Dokumentasi, analisa data menggunakan model interaktif, sedangkan pengujian keabsahan data dalam penelitian ini peneliti menggunakan Triangulasi Sumber.

\section{HASIL DAN PEMBAHASAN TEMUAN}

\section{HASIL TEMUAN}

Setelah dilakukan pengolahan dan analisa data yang telah penulis lakukan terkait dengan rumusan penelitian Pengembangan Program Pembelajaran Pendidikan Agama Islam dalam Meningkatkan Budaya Keagamaan di SDN Bletok Kecamatan Bungatan Kabupaten Situbondo, berdasarkan hasil wawancara, dan observasi. Maka ditemukan beberapa hal sebagai berikut: 
Pertama, Perencanaan pengembangan program pembelajaran Pendidikan Agama Islam dalam meningkatkan budaya keagamaan di SDN Bletok Kecamatan Bungatan Kabupaten Situbondo adalah sebagai berikut:

1. Adanya buku pintar, yang merupakan hasil evaluasi kegiatan-kegiatan tahun lalu,

2. Penugasan pada para kepala urusan untuk membuat rancangan baru untuk melengkapi keberhasilan kegiatan tahun lalu kemudian dibahas melalui rapat khusus.

3. Mutu menjadi pertimbangan utama dalam penyusunan perenacanaan.

4. Nilai-nilai karakter menjadi prioritas utama

5. Rencana strategis lebih pada pendekatan botton up

6. Perencanaan pengembangan program pembelajaran pendidikan agama islam dalam meningkatkan budaya keagamaan dilakukan oleh tim agama. $^{6}$

Kedua, pelaksanaan pengembangan program pembelajaran Pendidikan

Agama Islam dalam meningkatkan budaya keagamaan di SDN Bletok Kecamatan Bungatan Kabupaten Situbondo adalah:

1. Roling tanggung jawab job diskription pada tanggung jawab pengembangan budaya

2. Terdapat pada Quality Insurence (Jaminan Mutu) pembiasaan keagamaan

3. Model uswah guru

4. Budaya keagamaan dalam kehidupan di sekolah. ${ }^{7}$

Ketiga, pengawasan pengembangan program pembelajaran Pendidikan Agama Islam dalam meningkatkan budaya keagamaan di SDN Bletok Kecamatan Bungatan Kabupaten Situbondo adalah sebagai berikut:

1. Kontrol secara internal melalui pengawasan kinerja pada anggota organisasi dan sisi eksternal kontrol dilakukan dari pengguna layanan baik siswa maupun orang tua siswa.

\footnotetext{
${ }^{6}$ Wawancara dan observasi di SDN Bletok Tanggal 9 Juli 2020.

${ }^{7}$ Wawancaran dan Dokumentasi SDN Bletok Tanggal 9 Juli 2020.
} 
2. Evaluasi dilakukan oleh supervisor sekolah dengan intrumen-instrumen yang sudah disiapkan dalam evaluasi kinerja.

3. Tolak ukur keberhasilan Budaya keagamaan salah satu indikatornya adalah jika rata-rata seluruh siswa berprestasi secara akademik, berkepribadian baik sesuai dengan nilai-nilai agama, berdaya saing dan berwawasan global.

4. Monitoring dilakukan oleh komponen sekolah dan Tim agama.

5. Monitoring dilakukan setiap saat, tetapi di setiap akhir semester dilakukan penilaian kepada siswa.

6. Objek-objek dari monitoring tingkah laku maupun kegiatan pembiasaan yang dilakukan oleh anak- anak.

7. Nilai dari pembiasaan keagamaan untuk mengetahui seberapa jauh capaian dari Quality Insurence yang sudah ditetapkan. ${ }^{8}$

\section{PEMBAHASAN TEMUAN}

Berdasarkan hasil temuan penelitian ini tentang pengembangan program pembelajaran pendidikan agama Islam dalam meningkatkan budaya keagamaan di SDN Bletok Kecamatan Bungatan Kabupaten Situbondo. Dari temuan tersebut, maka peneliti secara mendalam dan terperinci akan mendeskripsikan tentang perencanaan, pelaksanaan dan pengawasan pengembangan program pembelajaran Pendidikan Agama Islam dalam meningkatkan budaya keagamaan di SDN Bletok Kecamatan Bungatan Kabupaten Situbondo, sebagai berikut:

Perencanaan Pengembangan Program Pembelajaran Pendidikan Agama Islam dalam Meningkatkan Budaya Keagamaan di SDN Bletok Kecamatan Bungatan Kabupaten Situbondo

Perencanaan pada dasarnya merupakan pengambilan keputusan sekarang tentang hal-hal yang akan dikerjakan di masa depan. Apabila berbicara tentang perencanaan yang menjadi pertimbangan utamanya adalah

\footnotetext{
${ }^{8}$ Wawancaran dan Observasi di SDN Bletok Tanggal 9 Juli 2020.
} 
Mutu dan Nilai-nilai karakter siswa. Setiap kegiatan mempunyai prosedur, yaitu suatu cara yang ditempuh dalam kegiatan itu untuk mencapai apa yang dicita-citakan. Prosedur dalam perencanaan adalah upaya yang ditempuh oleh para perencana untuk merealisasi usahanya agar dapat terwujud suatu konsep perencanaan. Prosedur perencanaan adalah langkah-langkah yang ditempuh dalam proses perencanaan. Prosedur yang ditempuh oleh setiap perencana organisasi maupun perorangan seringkali berbeda dan bervariasi, tetapi dalam garis besarnya sama.

Perencanaan adalah menyusun langkah-langkah yang akan dilaksanakan untuk mencapai tujuan yang telah ditentukan. Menurut Abdul Majid perencanaan adalah menentukan apa yang akan dilakukan. Perencanaan mengandung rangkaian-rangkaian putusan yang luas dan penjelasan-penjelasan dari tujuan, penentuan kebijakan, penentuan program, penentuan metode-metode dan prosedur tertentu dan penentuan kegiatan berdasarkan jadwal sehari-hari. ${ }^{9}$ Dengan demikian perencanaan merupakan sebuah skenario pembelajaran yang akan dilaksanakan oleh guru sebelum mengajar.

Dalam menyusun perencanaan di SDN Bletok Kecamatan Bungatan, terlebih dahulu melakukan evaluasi, dimana terdapat buku pintar, yang merupakan hasil evaluasi kegiatan-kegiatan tahun lalu. Hasil evaluasi ini menjadi acuan untuk menatap masa depan yang lebih baik, artinya temuantemuan yang sebelumnya dapat dijadikan bahan evaluasi, pada aspek mana kekurangan-kekurangan itu ada, sehingga dalam hal ini Perencanaan di SDN Bletok Kecamatan Bungatan berfungsi untuk memandang masa depan dan menciptakan kerangka kerja untuk mengarahkan tindakan seseorang di masa depan yang lebih baik. ${ }^{10}$

\footnotetext{
9 Abdul Majid, Perencanaan Pembelajaran: Mengembangkan Standar Kompetensi Guru (Bandung: PT. Remaja Rosdakarya, 2012), 15.

${ }^{10}$ Syafarudin dan Irwan Nasution, Manajemen Pembelajaran..., 91.
} 
Selanjutnya rencana strategik lebih pada pendekatan botton up. Rencana strategik ini dilakukan berdasarkan pendekatan dari bawah keatas artinya kepala sekolah SDN Bletok Kecamatan Bungatan, Sejatinya setiap kegiatan baik dalam organisasi maupun lembaga pendidikan memiliki strategi baik berupa pertimbangan-pertimbangan, perbandingan dengan kegiatan lain, kebijakan yang perlu dilakukan, dan pendekatan yang terbaik agar tujuan yang diinginkan tepat dan bisa dicapai. Strategi tersebut biasanya terlebih dahulu dirumuskan ke dalam sebuah perencanaan hingga kemudian dikenal dengan istilah perencanaan strategis dengan maksud agar hasil perencanaan yangberupa tujuan, visi maupun misi organisasi dapat dicapai dengan baik, tuntas, efektif dan efisien. Strategi itu sendiri adalah pola tindakan terpilih untuk mencapai tujuan tertentu.

Secara mendasar terdapat empat pendekatan dasar terhadap perencanaan namun yang terdapat di SDN Bletok Kecamatan Bungatan adalah bottom-up approach, Pendekatan dari bawah ke atas (bottom-up approach) Perumusan strategis dalam pendekatan ini diambil dari berbagai unit atau divisi organisasi lalu kemudian disampaikan ke atas untuk disatukan pada tingkat organisasi. Dalam hal ini personalia organisasi diberikan kepercayaan penuh untuk menyumbangkan aspirasinya mengenai strategi organisasi dalam rangka pencapaian tujuan organisasi agar lebih efektif dan efisien.

Sedangkan Perencanaan pengembangan program pembelajaran pendidikan agama Islam dalam meningkatkan budaya keagamaan di SDN Bletok Kecamatan Bungatan dilakukan oleh tim agama, Setidaknya terdapat beberapa alasan rencana guru menjadi penting, yaitu: Untuk mengurangi kecemasan dan ketidak pastian; Memberikan pengalaman pembelajaran bagi guru; Perencanaan membolehkan para guru untuk mengakomodasi 
perbedaan individu diantara siswa; Memberikan struktur dan arah untuk pembelajaran. ${ }^{11}$

Dari temuan tersebut Kepala sekolah di SDN Bletok Kecamatan Bungatan memberikan Penugasan pada para kepala urusan untuk membuat rancangan baru untuk melengkapi keberhasilan kegiatan tahun lalu kemudian dibahas melalui rapar khusus.

\section{Pelaksanaan Pengembangan Program Pembelajaran Pendidikan} Agama Islam dalam Meningkatkan Budaya Keagamaan di SDN Bletok Kecamatan Bungatan Kabupaten Situbondo

Implementasi kurikulum merupakan penerapan atau pelaksanaan program kurikulum yang telah dikembangkan dalam tahap sebelumnya, kemudian diuji cobakan dengan pelaksanaan dan pengelolaan, sambil senantiasa dilakukan penyesuaian terhadap situasi lapangan dan karakteristik peserta didik, baik perkembangan intelektual, emosional, serta fisiknya. Implementasi ini juga sekaligus merupakan penelitian lapangan untuk keperluan validasi sistem kurikulum itu sendiri. ${ }^{12}$

Maka dalam hal ini, pembelajaran di dalam kelas merupakan tempat yang tepat untuk melaksanakan dan menguji validasi kurikulum. Dalam kegiatan pembelajaran semua konsep, prinsip, nilai, pengetahuan, metode, alat, dan kemampuan guru diuji dalam bentuk perbuatan, yang akan mewujudkan bentuk kurikulum yang nyata. Perwujudan konsep, prinsip, dan aspek-aspek kurikulum tersebut seluruhnya terletak pada kemampuan Dosen sebagai implementator kurikulum. Oleh karena itu, gurulah kunci pemegang pelaksana dan keberhasilan kurikulum. Gurulah yang bertindak sebagai perencana, pelaksana, penilai, dan pengembang kurikulum yang sebenarnya. Untuk itu, dalam mengelola implementasi kurikulum aspek kemampuan atau kompetensi guru perlu mendapat perhatian yang serius.

\footnotetext{
${ }^{11}$ Syafarudin dan Irwan Nasution, Manajemen Pembelajaran..., 94.

12 Oemar Hamalik, Dasar-Dasar Pengembangan Kurikulum, 238.
} 
Guru dalam pelaksanaan pembelajaran di dalam kelas merupakan figur sentral dalam mengantarkan manusia yaitu peserta didik kepada tujuan yang mulia. Nana Syaodih Sukmadinata dalam Ramayulis menyebutkan bahwa guru memegang peranan kunci bagi keberlangsungan pendidikan. karena guru yang selalu berinteraksi langsung dengan peserta didik dalam kegiatan pembelajaran. Keberhasilannya dalam mencapai tujuan tersebut, merupakan sebagai kesuksesan dalam menjalankan tugasnya sebagai guru yang proporsional dan professional. ${ }^{13}$

Pelaksanaan pengembangan program pembelajaran Pendidikan Agama Islam dalam meningkatkan budaya keagamaan di SDN Bletok Kecamatan Bungatan dilakukan dengan jalan Roling tanggung jawab job description pada tanggung jawab pengembangan budaya, Terdapat pada Quality Insurence (Jaminan Mutu) pembiasaan keagamaan, Model uswah guru.

Selain itu, pelaksanaan Budaya keagamaan pertama, komitmen dan motivasi guru. Kedua, mayoritas guru yang relatif masih muda dan bersemangat. Ketiga, kualitas peserta didik yang bagus melalui seleksi yang ketat. Keempat, budaya sekolah sudah terprogram. Kelima, tingkat kepercayaan masyarakat terhadap sekolah cukup tinggi. Keenam, kesadaran orang tua siswa tentang kualitas pendidikan. Ketujuh, memiliki tempat khusus pembelajaran agama yang bisa menjaring siswa berprestasi.

\section{Pengawasan Pengembangan Program Pembelajaran Pendidikan}

Agama Islam dalam Meningkatkan Budaya Keagamaan di SDN Bletok

\section{Kecamatan Bungatan Kabupaten Situbondo}

Pengendalian pengembangan program pembelajaran Pendidikan Agama Islam dalam meningkatkan budaya keagamaan di SDN Bletok Kecamatan Bungatan diantaranya adalah Kontrol secara internal melalui pengawasan kinerja pada anggota organisasi dan sisi eksternal kontrol

\footnotetext{
${ }^{13}$ Ramayulis, Profesi dan Etika Keguruan, (Jakarta: Kalam Mulia, 2013), 10.
} 
dilakukan dari pengguna layanan baik siswa maupun orang tua siswa. Evaluasi dilakukan oleh supervisor sekolah dengan intrumen-instrumen yang sudah disiapkan dalam evaluasi kinerja.

Tolak ukur keberhasilan Budaya keagamaan salah satu indikatornya adalah jika rata-rata seluruh siswa berprestasi secara akademik, berkepribadian baik sesuai dengan nilai-nilai agama, berdaya saing dan berwawasan global. Monitoring dilakukan oleh komponen sekolah dan Tim agama, Monitoring dilakukan setiap saat, tetapi di setiap ahir semester dilakukan penilaian kepada siswa, Objek objek dari monitoring tingkah laku maupun kegiatan pembiasaan yang dilakukan oleh anak- anak. Nilai dari pembiasaan keagamaan untuk mengetahui seberapa jauh capaian dari Quality Insurence yang sudah ditetapkan.

Istilah pengawasan dapat mengandung arti beragam, yaitu dapat berarti inspeksi, kontrol dan evaluasi dalam proses manajemen. Pengawasan padaha kekatnya adalah suatu aktivitas dalam usaha mengendalikan, menilai dan mengembangkan kegiatan organisasi agar sesuai dengan rencana dan tujuan yang telah ditetapkan sebelumnya. ${ }^{14}$

Pengawasan di SDN Bletok Kecamatan Bungatan merupakan tindakan atau proses kegiatan untuk mengendalikan pelaksanaan. Kesalahan, kegagalan, penyimpangan yang terjadi pembiasaan keagmaan yang perlu diperbaiki dan dicegah jangansampai terulang kembali kesalahan-kesalahan tersebut, dan juga menjaga agar pelaksanaan tidak berbeda dengan rencana yang telah ditetapkan. M. Manullang sebagaimana yang dikutip Soetopo mengartikan pengawasan sebagai proses untuk menetapkan pekerjaan apa yang sudah dilaksanakan, menilainya dan mengoreksi bila perlu, dengan maksud supaya pelaksanaan pekerjaan sesuai dengan rencana semula. ${ }^{15}$

\footnotetext{
${ }^{14}$ Hendyat Soetopo, Manajemen Pendidikan ( Bahan Kuliah Manajemen Pendidikan Bagi Mahasiswa S2), (Malang: Pascasarjana-Univ. Negeri Malang, 2001), 76

${ }^{15}$ Hendyat Soetopo, Manajemen Pendidikan...76
} 
Pengawasan adalah proses membandingkan untuk kerja aktual dengan standard yang telah ditetapkan sebelumnya dan melakukan perbaikan yang diperlukan. Berdasarkan penjelasan tersebut, maka dapat diambil beberapa maknapengertian pengawasan sebagai berikut: (1) Pengawasan merupakan proses aktivitas, (2) Pengawasan berusaha mengecek, menilai, dan mengoreksi, (3) Kriteria pengecekan adalah rencana, perintah dan prinsip, dan (4) Tujuan pengawasan adalah mengendalikan dan mengembangkan kegiatan organisasi. Dan apabila dirinci lebih jauh bahwa tujuan pengawasan adalah: (1) Agar pelaksanaan tugas sesuai dengan ketentuan, prosedur serta perintahyang telah ditetapkan, (2) Agar hasil yang dicapai sesuai dengan tujuan yangtelah ditetapkan, (3) Agar sarana yang ada (fasilitas, tenaga, biaya, pikiran) dapat di dayagunakan secara efektif dan efisien, (4) Agar diketahui kelemahan dan kesulitan organisasi, kemudian dicari jalan perbaikannya.

Berdasarkan tujuan yang ingin dicapai tersebut, maka pengawasan dapat diharapkan mencapai target sebagai berikut: a) Adanya kepastian di SDN Bletok Kecamatan Bungatan bahwa kuantitas dan kualitas pekerjaan benar-benar tercapai b) Pemborosan bahan, tenaga, biaya, pikiran, ruang dan waktu dapat dibatasi seminimal mungkin c) Dapat diketahui kemajuan tiaptiap taraf kegiatan dan langkah-langkah kegiatan d) Dapat digunakannya pendekatan terbaik dalam melaksanakan kegiatan.

Dapat diketahui ada atau tidaknya perubahan, perbaikan dan penyesuaian rencana, organisasi, bimbingan, pengarahan, dan sistem yang diterapkan Secara singkat dapat dikatakan bahwa tujuan pengawasan adalah preventif dan represif. Preventif mengacu pada pencegahan timbulnya penyimpangan pelaksanaan kerja organisasi dari perencanaan yang telah disusun sebelumnya.

Represif berarti bahwa usaha mencapai ketataan dan kedisiplinan menjalankan setiap aktivitas agar memiliki kepastian hukum dan menetapkan perbaikan jika terdapat penyimpangan. Oleh sebab itu, antara 
perencanaan dan pengawasan mempunyai hubungan yang sangat erat. "Planning and Controling are the two sides ofthe same coin" yang artinya perencanaan dan pengawasan merupakan dua sisimata uang yang sama. Tanpa pengawasan, penyimpangan akan terus berlangsung dan semakin parah, sehingga sulit mengatasinya. Pengawasan yang efektif menjamin tercapainya tujuan yang telah direncanakan. ${ }^{16}$

Pelaksanaan pengawasan didasarkan pada prinsip-prinsip yang melandasinya. Adapun prinsip-prinsip pengawasan yang dimaksud antara lain: a) Prinsip organisasi, artinya pengawasan harus dilaksanakan dalam kerangka struktur organisasi yang melingkupnya. Misalnya organisasi sekolah, pengawasan dilakukan terhadap jalannya organisasi internsekolah dan hasil kontrol atau pengawasan itu dilaporkan kepada unit organisasi di atasnya. b) Prinsip perbaikan, artinya pengawasan berusaha mengetahui kelemahan atau kekurangan, kemudian dicari jalan pemecahan agar manajemen dapat berjalan sesuai dengan standard dan organisasi dapat mencapai tujuan. c) Prinsip komunikasi, artinya pengawasan dilakukan untuk membina sistem kerjasama antara atasan dan bawahan, membina hubungan baik antara atasan dan bawahan dalam proses pelaksanaan pengelolaan organisasi. d) Prinsip pencegahan, artinya pengawasan dilakukan untuk menghindari adanya kesalahan dalam mengelola komponen-komponen organisasi. e) Prinsip pengawasan, artinya pengawasan dilakukan agar semua proses pengembangan pembelajaran berada pada rel yang telah digariskan sebelumnya. g) Prinsip kontinyuitas, artinya pengawasan dilakukan secara terus menerus, baik selama berlangsungnya proses pelaksanaan maupun setelah pelaksanaan kerja. Dengan demikian pengawasan dilakukan terhadap proses dan hasil.

\footnotetext{
${ }^{16}$ Hendyat Soetopo, Manajemen, 13.
} 


\section{SIMPULAN}

Pengembangan Program Pembelajaran Pendidikan Agama Islam dalam Meningkatkan Budaya Keagamaan di SDN Bletok Kecamatan Bungatan Kabupaten Situbondo, yaitu: 1) Perencanaan Pengembangan Program Pembelajaran Pendidikan Agama Islam Dalam Meningkatkan Budaya Keagamaan di SDN Bletok Kecamatan Bungatan Kabupaten Situbondo: penyusunan buku pintar, Penugasan pada para kepala urusan membuat rancangan kegiatan, pertimbangan mutu dalam penyusunan perenacanaan, Nilai-nilai karakter menjadi prioritas utama, Rencana strategis dengan pendekatan botton up, perencanaan pengembangan budaya keagamaan oleh tim agama. 2) Pelaksanaan Pengembangan Program Pembelajaran Pendidikan Agama Islam Dalam Meningkatkan Budaya Keagamaan di SDN Bletok Kecamatan Bungatan Kabupaten Situbondo, yaitu: Roling tanggung jawab job diskription pengembangan budaya, Quality Insurence (Jaminan Mutu) pembiasaan keagamaan, Model uswah guru, pelaksanaan Budaya keagamaan. 3) Pengawasan Pengembangan Program Pembelajaran Pendidikan Agama Islam Dalam Meningkatkan Budaya Keagamaan di SDN Bletok Kecamatan Bungatan Kabupaten Situbondo, yaitu: pengawasan internal melalui pengawasan kinerja anggota organisasi dan eksternal melalui pengguna layanan baik siswa maupun orang tua siswa, evaluasi dilakukan oleh supervisor sekolah dalam evaluasi kinerja, berkepribadian baik sesuai dengan nilai-nilai agama, monitoring dilakukan oleh komponen sekolah dan Tim agama, monitoring siswa, monitoring tingkah laku dan kegiatan pembiasaan siswa, penetapan capaian dari Quality Insurence. 


\section{DAFTAR PUSTAKA}

Hamalik, Oemar. Dasar-Dasar Pengembangan Kurikulum. Bandung: Rosda Karya. 2007.

Http://www.unesco.org/delors/fourpil.htm, diakses pada 14 Oktober 2020.

Majid, Abdul. Perencanaan Pembelajaran: Mengembangkan Standar Kompetensi Guru. Bandung: PT. Remaja Rosdakarya, 2012.

Ramayulis. Profesi dan Etika Keguruan. Jakarta: Kalam Mulia, 2013.

Soetopo, Hendyat. Manajemen Pendidikan (Bahan Kuliah Manajemen Pendidikan Bagi Mahasiswa S2). Malang: Pascasarjana-Univ. Negeri Malang, 2001.

Suyadi, Pelaksanaan Pembelajaran Pendidikan Agama Islam (PAI) DI SMK Negeri 1 Lais Kecamatan Lais Kabupaten Musi Banyuasin, Jurnal Conciencia, Vol. 14 No 1 (2014), 37.

Syafarudin dan Irwan Nasution. Manajemen Pembelajaran, Jakarta: Quantum Teaching, 2005.

Undang-undang Republik Indonesia Nomor 11 Tahun 2019 Tentang Sistem Nasional Ilmu Pengetahuan Dan Teknologi. 